\title{
Religion and Reactance to COVID-19 Mitigation Guidelines
}

\author{
David DeFranza $^{* \dagger}$ \\ Mike Lindow* \\ Kevin Harrison* \\ Arul Mishra* \\ Himanshu Mishra* \\ * David Eccles School of Business, University of Utah \\ ${ }^{\dagger}$ Correspondence concerning this article should be addressed to David DeFranza, David Eccles School \\ of Business, University of Utah, 1665 Campus Center Dr., Salt Lake City, UT 84112. Email: \\ david.defranza@eccles.utah.edu
}

Forthcoming: American Psychologist

CAmerican Psychological Association, 2020. This paper is not the copy of record and may not exactly replicate the authoritative document published in the APA journal. Please do not copy or cite without author's permission. The final article is available, upon publication, at:

https://doi.org/10.1037/amp0000717 


\begin{abstract}
During the current COVID-19 pandemic, religious gatherings have become intense hot spots for the spread of the virus. In this research, we focus on the religiosity of communities to examine whether religiosity helps or hinders adherence to mitigation policies such as shelter-in-place directives. Prior research makes opposing predictions as to the influence of religiosity. One stream predicts greater adherence because of rule-abiding norms and altruistic tendencies while another predicts lower adherence as a reaction against the restriction of personal and religious freedom. We used shelter-in-place directives as an intervention in a quasi-experiment to examine adherence over 30 days as a function of religiosity in the most populous metropolitan areas in the United States. When a shelter-in-place directive had not been imposed, religiosity did not affect people’s movements. However, when the directive was imposed, higher religiosity resulted in less adherence to shelter-in-place directives.
\end{abstract}

\title{
Public Significance
}

Federal, state, and local governments have raced to implement policies and directives to curb the spread of COVID-19 in the United States. One such important policy has been the issuance of shelter-in-place directives. Our research shows that, across the 53 largest municipal regions in the country, these directives have largely been effective in reducing movement and activities. However, we also find that greater religiosity in a community leads to increased reactance to the policy and decreased adherence. Our findings can inform policy makers that the same directive can elicit less versus more adherence depending on how communities perceive it. 
Religion is an important component of people's lives. About $80 \%$ of people in the United States categorize themselves as following a religion (Pew Forum, 2008). During times of pandemics, higher mortality salience triggers religiosity and prayerfulness (Schuster et al., 2001; Thunström \& Noy, 2019). Historically, calamities have intensified religious beliefs, from medieval times to the recent past. The Black Death in medieval Europe, the 1918 Flu in South Africa, smallpox in India, or the September 11, 2001 attacks in the United States all elicited greater religiosity (Ai et al., 2005; Osheim, 2008; Poulin et al., 2009; Torabi \& Seo, 2004). Across the world, calamities have been perceived as a sign of divine wrath, and even led to the creation of new deities (Osheim, 2008). For much of history, it was common for religious and medical care to be provided by the same individual (Aukst-Margeti \& Margeti, 2005). Given the historical association between religiosity and calamities (Osheim, 2008), it is not surprising that people have turned to religion for solace during the COVID-19 pandemic (Wilson et al., 2020). Over half of Americans have prayed for the end of the COVID-19 pandemic and 24\% of Americans have reported an increase of faith during the COVID-19 pandemic (Gecewicz, 2020). However, in many countries, religious gatherings such as in the Tablighi Jamaat (India), Shincheonji Church (South Korea), and Kyiv Pechersk Lavra (Ukraine) have become intense hot spots for the spread of the virus. In the United States, funerals, choir practices, and church services have led to super-spreader incidents in which one person infects a disproportionate number of other individuals (Aschwanden, 2020).

To date, COVID-19 has no viable vaccine and treatment at scale has been challenging (Cunningham et al., 2020; Arabi et al., 2020). Given advances in the scientific understanding of disease transmission, officials have recommended hand washing, sanitizing, and most 
importantly social-distancing and shelter-in-place measures as prophylactics, but these measures are not a panacea. In times of uncertainty, it is not surprising that people might turn to religion for solace (Wilson et al., 2020). Google searches for prayer rose to record breaking levels during the COVID-19 pandemic across all levels of income, inequality, and insecurity (Bentzen, 2020). However, it is worth examining whether religiosity would help or hinder mitigation policies. The aim of this research is to examine how religiosity impacts adherence to directives such as shelterin-place which are designed to reduce the spread and mortality of disease. The COVID-19 pandemic provided a way to examine the impact of religiosity on community health and welfare. We first present two streams of research that inform our research question.

\section{Theory and Predictions}

Religiosity is a multi-dimensional construct. It can be defined as feelings, thoughts, experiences, and behaviors that are associated with God or the sacred (Hill et al., 2000). Religiosity has been shown to predict several life outcomes. For instance, greater religiosity positively correlates with ego strength (e.g., hope, will, purpose, love; Markstrom, 1999), better self control (Laird et al., 2011), and improved health status (Brown \& Gary, 1994).

Given its multi-dimensional nature and influence on various aspects of life, the quantification of religiosity has been challenging and problematic (Hill \& Edwards, 2013). Indeed, the history of the study of religion in psychology has focused on measurement development and refinement (Gorsuch, 1984). One stream of literature captures such a multidimensional aspect through the dimensions of experiential or personal beliefs, community behaviors, doctrinal beliefs, or the cognitive processes associated with the knowledge of religious tenets (Fukuyama, 1961; Hall et al., 2008; Holdcroft, 2006). For the purposes of the 
current research, we focus on the community dimensions of religiosity (Mathras et al., 2016) since we want to examine how this aspect of religiosity affects the response to COVID-19 directives, specifically, how the behaviors of a religious community would change (or not).

We use religious density as a measure of religiosity. Religious density is quantified as the number of congregations per 10,000 residents and has been used as a measure of religiosity in past work (McClure, 2017; Scala \& Johnson, 2017; Snell, 2014; Williams \& O’Leary, 2019). An increase in religious density in a community has been called plurality, which is said to reflect religious competition. As religious density increases, the competition for members increases, which leads to an increase in public expression of belief. Such plurality can result in greater social, community, and charitable engagement of members (Borgonovi, 2008; Fox \& Tabory, 2008; Iyer, 2016; McBride, 2008).

To examine whether religiosity would hinder or facilitate adherence to shelter-in-place directives, we are guided by two streams of research that make opposing predictions. While one suggests that religiosity should increase adherence, the other finds evidence against such adherence. The first stream argues religiosity reflects a general willingness to follow rules provided by authorities. For instance, religious priming has been found to activate more submissive thoughts and subsequent behaviors (Saroglou et al., 2009) and religious individuals were more likely to align with group consensus (Van Cappellen et al., 2011). In fact, religion inculcates an obligation to follow rules, especially those that differentiate good and evil (Torgler, 2006). Individuals with a tendency toward greater religiosity are more open to following guidelines, irrespective of whether they are religious or secular. For example, higher levels of religiosity have been associated with increased rates of tax compliance (Torgler, 2006) and 
higher compliance for critical decisions such as organ donation (Guéguen et al., 2015). Such an obligation to follow rules occurs from a very young age if a child is brought up in a religious family (Smith et al., 1998). Moreover, religiosity promotes greater self-control, which in turn helps people follow rules more easily because they can control their desire to break rules (Desmond et al., 2013). Taken together, this stream of research suggests that the combination of greater willingness to abide by the rules and an increased ability to exert self-control associated with higher religiosity should result in more adherence to shelter-in-place directives.

The second stream of research has suggested that rule-following among the religious is not guaranteed. For instance, research has demonstrated that when religiosity increases, people perceive greater support from the divine, which in turn provides them with a feeling of divine support through adverse situations. Such an increased reliance on the divine reduces compliance to fear-based recommendations (Wu \& Cutright, 2018).

Specific to our question of adherence to health guidelines, past research has found participation in a religious community correlates positively with mental and physical well-being (Aukst-Margeti \& Margeti, 2005). Prior research has suggested that religious membership can improve and sustain the health of its members through social support during difficult life events, which in turn can reduce stress (Williams et al., 1991). Such affiliation can also promote healthier living habits for its members which can improve physical and mental well-being. A meta-analysis of 42 studies, for example, found that religiosity increases longevity with public religious commitment (e.g., gathering and ceremonial attendance) being a stronger predictor of longevity than private commitment (McCullough et al., 2000). Since participation in a religious community is associated with reduced stress and increased well-being, individuals with greater 
religiosity may be more willing to ignore shelter-in-place directives when they limit access to such a community.

In the context of COVID-19, social-distancing and shelter-in-place measures have resulted in many social changes, including the cancellation of sporting and entertainment events, the closure of schools and colleges, and the widespread adoption of remote work. Religious gatherings have also fallen under the purview of these directives, which has caused an uproar in several religious communities (Wilson et al., 2020). During the week of Easter, for example, many Christian communities argued that drive-in services should be permitted (The Associated Press, 2020). If a directive seems to curtail any aspect of religion (e.g., the ability of the community to congregate), religious adherents may react against the directive, either by questioning its utility or refusing to comply outright. Since religious freedom is a form of personal freedom, restrictions, especially those imposed by government agencies, can increase opposition. In the case of the COVID-19 pandemic, many of the directives restrict religious gatherings and hence adherence to directives could be perceived as a restriction on personal freedoms. Therefore, if people were to focus on the communal dimensions of religious practice, they might perceive the directives as restrictions against their religiosity. This stream of research, therefore, predicts that mitigation directives could result in increased skepticism and reduced adherence.

In our research, we examine which of these predictions are likely to hold: whether greater religiosity would result in more or less adherence to shelter-in-place and social-distancing directives.

\section{Methods}




\section{A Quasi-Experiment}

In the wake of rapidly spreading COVID-19 infections, several states implemented shelter-in-place directives. This provided an unusual setting in which data about community behavior was available before and after the directives were implemented. This unique situation allows us to examine the influence of religiosity on adherence to directives and test opposing predictions from two different theoretical accounts. The shelter-in-place directives provided a naturalistic intervention (Harrison \& List, 2004; List, 2007; Meyer, 2012) amenable to generalized difference-in-differences analysis (Wing et al., 2018; Lechner, 2011). Using publicly available indicators of religion in large metropolitan areas of the United States, we tested the impact of aggregate religiosity on adherence to COVID-19 mitigation directives across 30 days in the most populous 53 metropolitan areas in the United States.

Aggregate religiosity was measured using the number of congregations per 10 thousand residents (Kane, 2013; Djupe et al., 2018). This variable allowed us to objectively examine religiosity across the country, rather than sample religiosity through self-report, which tends to suffer from socially desirable responding (Brenner, 2011, 2014) and does not form a robust connection between attitudes and behavior (Hill \& Edwards, 2013; Pichon et al., 2007; Rossi \& Scappinni, 2014; Sagolou et al., 2005). Congregations per 10 thousand residents has been used to measure the influence of religiosity on a host of variables such as political behavior (Snell, 2014; Scala \& Johnson, 2017), pro-social behavior (McClure, 2017), vaccine attitudes (Williams \& O’Leary, 2019), settlement patterns (Donnermeyer et al., 2019), and managerial decision making (Cui et al., 2015). 
In order to measure adherence to shelter-in-place directives, we again used a publicly available indicator of actual adherence-localized $\mathrm{PM}_{2.5}$ pollution levels—rather than attitudinal measures. $\mathrm{PM}_{2.5}$ is closely associated with local vehicular movement and industrial activity. If people in a specific region followed shelter-in-place directives, there should be a decrease in $\mathrm{PM}_{2.5}$ levels. We conducted robustness checks for our focal analysis by controlling for locationspecific, time-varying variables such as COVID-19 infection and death rates at the metropolitan area level, meteorological variables known to affect $\mathrm{PM}_{2.5}$ levels (such as precipitation), and the 5-year average $\mathrm{PM}_{2.5}$ level for each metropolitan area, for each date, to control for seasonal variations in $\mathrm{PM}_{2.5}$ levels. In addition, we used variables such as unemployment rate and poverty level to control for the influence of industrial and economic activities.

\section{Data}

We considered the most populous 53 metropolitan statistical areas (hereafter referred to as metropolitan areas) with a population over one million, which included most of the 50 states and of which 43 implemented a shelter-in-place directive during our observation period. The data is a cross-sectional time-series, collected from the metropolitan areas over a 30 day period between February 29, 2020 and March 29, 2020 (N = 1590; see Supplemental Material A for a detailed description of variables and data sources). February 29 was selected as the starting point for observation because the first COVID-related death in the United States was announced on this day (Centers for Disease Control and Prevention, 2020). Data was collected for approximately one month (30 days) following the initial event. We next describe the intervention variable (i.e., shelter-in-place directives), predictor variable (i.e., religiosity), outcome variable (i.e., adherence to the directive), and control variables. 
Shelter-in-place intervention. Since metropolitan areas did not implement shelter-in-place directives simultaneously, a dummy variable indicating when the metropolitan area implemented a directive served as the intervention variable.

Religiosity. We used religiosity data from the 2010 U.S. Religion Census, conducted by the Association for Statisticians of American Religious Bodies, and provided by the Association of Religious Data Archives (Grammich et al., 2018). This census reports county-level counts of the number of congregations for each of 236 faith groups. The variable used in the analysis was the number of congregations per 10 thousand residents and hence, is not affected by the population of a state or metropolitan area. County-level values were aggregated to the level of the metropolitan area by taking a mean of counties in that metropolitan area, weighted by the population of that county as a proportion of the total metropolitan area.

Adherence. As a measure of adherence to shelter-in-place directives, we used $\mathrm{PM}_{2.5}$ levels in each of the metropolitan areas. $\mathrm{PM}_{2.5}$ is a measure of particulate matter with a diameter less than 2.5 micrometers, consistently produced by either combustion or re-entrainment from vehicular movement and industrial activity (Thurston et al., 2011). However, engine combustion and transportation activity is the single largest contributor to local $\mathrm{PM}_{2.5}$ levels, accounting directly for more than $25 \%$ of the total (Thurston et al., 2011). Hourly pollution data was collected from the EPA website via their public API. The mean pollution measure for each day from 0:00-23:59 GMT was recorded for each metropolitan area.

Control variables. Robustness checks of our focal analysis were conducted by controlling for location-specific and time-varying variables such as COVID-19 infection and death rates for each metropolitan area at a specific time. Meteorological variables known to affect $\mathrm{PM}_{2.5}$ levels 
such as temperature, wind speed, and precipitation were also added to the model (Yadav et al., 2014; Zalakeviviute et al., 2018). To control for seasonal and annual variations in $\mathrm{PM}_{2.5}$ levels, a 5-year average $\mathrm{PM}_{2.5}$ level for each metropolitan area, for each day of the 30 day period, and a dummy variable for day of the week, was added to the model (see Supplemental Material A for more details).

As economic and industrial activity can influence people's movement, additional control variables, including county-level bachelor's degree attainment (U.S. Census Bureau, 2019a), state-level unemployment (U.S. Department of Labor, 2020), and county-level poverty rates (U.S. Census Bureau, 2019b) were added. To account for regional variation in attitudes and behavior, the geographic region of the metropolitan area (U.S. Census Bureau, 2020) was added as a control. Finally, to control for people's movement due to their membership in social groups, the number of social membership groups in a community (University of Wisconsin Public Health Institute, 2020) were added. All the variables were aggregated from the level of county to metropolitan area using the method described previously.

In our data set, eight cases in the time period of interest were missing measures of pollution ( $\mathrm{PM}_{2.5}$, the dependent variable in our analysis) and one case was missing a previous five-year average of $\mathrm{PM}_{2.5}$ (a control variable in our analysis). These values were imputed using fully conditional specification, which estimates a joint density for each missing case in each variable, allowing for a flexible multiple imputation scheme when no known suitable multivariate distribution is available (Buuren \& Groothuis-Oudshoorn, 2011).

\section{Model Specification}


Because the data is panel in nature, grouped by metropolitan area with an individual time series for each, an ordinary least squares (OLS) regression analysis is not suitable. Therefore, the econometric analysis we used utilized two common models for panel data: a fixed effects model and a random effects model (Hsiao, 2014). The fixed effects model assumes that for every metropolitan area, there are many time-invariant variables (e.g., population during the 30 day period). Some of these variables are observable (e.g., population) and some are unobservable (e.g., the culture of a metropolitan area). These variables may impact the $\mathrm{PM}_{2.5}$ levels and other time varying predictor variables. Therefore, a fixed effects model removes the influence of timeinvariant, fixed variables to assess the influence of time-varying predictors on the outcome variable. It is important to note that while religiosity is time-invariant, the focal interaction of religiosity with shelter-in-place directives is time-varying and thus amenable to an assessment by a fixed effects model. A random effects model, on the other hand, assumes that the time-invariant characteristics are uncorrelated with the time-varying predictors. This allows us to assess the influence of time-invariant characteristics on the outcome variable.

The model (without control variables) had the following form, where $m$ represents metropolitan area and $t$ represents time:

$$
\text { Adherence }_{m, t}=\mu_{t}+\beta S I P_{m, t}+\lambda \text { Religion }_{m}+\delta\left(\text { Religion }_{*} S I P\right)+\epsilon_{m, t}
$$

where Adherence $e_{\mathrm{m}, \mathrm{i}}$ is $\mathrm{PM}_{2.5}$ level, $S I P_{m, t}$ is a shelter-in-place intervention dummy variable with value zero if shelter-in-place was not implemented at time $t$ and one if it was implemented. Religiosity $y_{m}$ is time-invariant for a metropolitan area, $\varepsilon_{m, t}$ is random disturbance and $\mu_{t}$ is the intercept that is allowed to vary over time. $\beta, \lambda$, and $\delta$ are coefficients.

\section{Results}


The first set of tests that we performed assessed whether there was any evidence of significant differences across metropolitan areas and over the time period. Had there been no significant differences, an OLS model could have been used. An F-test indicated that the twoway fixed effects model is preferred over the OLS regression model $(F(69,1500)=7.3196, p<$ 0.0001). Similarly, a two-way random effects model is also preferred over the OLS model (Breusch-Pagan Lagrange Multiplier Test, $\chi^{2}(1)=240.18, p<0.0001$ ). Between the two-way random and two-way fixed effects model, the Hausman test revealed that the random effects model is preferred over the fixed effects model $\left(\chi^{2}(8)=7.2552, p=0.5094\right)$. Table 1 presents the results of the two-way random effects model (column two) along with the results of random effects model after including control variables (column three). However, the results are quite consistent across two-way random effects, fixed effects, and pooled OLS regression models (see Supplemental Material B). Here we report the results from the random effects model with control variables from Table 1 to explain the relationship between predictors and the outcome variable. We first discuss the main effects and then the interactions.

The main effects that emerged from the two-way random effects analysis indicated the following: As precipitation increased, $\mathrm{PM}_{2.5}$ levels fell $(\beta=-0.0042, p<0.001)$, a pattern that is consistent with the influence of precipitation on $\mathrm{PM}_{2.5}$ levels (Yadav et al., 2014). No regionspecific effects were observed nor was a relationship between $\mathrm{PM}_{2.5}$ levels and wind speed or temperature during the time period of analysis, so these variables are excluded from models reported in Table 1. The presence of a shelter-in-place order did significantly affect $\mathrm{PM}_{2.5}$ levels $(\beta=-3.6931, p<0.001)$. When shelter-in-place guidelines were implemented, $\mathrm{PM}_{2.5}$ levels fell, suggesting people stayed home and movement was reduced. There was no significant 
relationship between the number of confirmed cases or deaths in a metropolitan area on $\mathrm{PM}_{2.5}$ levels. Aggregate religiosity (measured via congregation density in a metropolitan area) had no relationship with $\mathrm{PM}_{2.5}$ levels on its own, showing that irrespective of religiosity of a metropolitan area, the rate of movement and activity was roughly the same. Similarly, $\mathrm{PM}_{2.5}$ levels did not vary significantly by day of the week. This suggests that higher levels of weekday activity due to regular business traffic and commuting were offset on the weekends by higher levels of recreational traffic or travel to and from religious gatherings.

While there was no direct relationship between religiosity of a metropolitan area and $\mathrm{PM}_{2.5}$ levels, the interaction between religiosity and the issuance of a state-wide shelter-in-place directive was significant. As depicted in the plot of marginal effects of this interaction (see Figure 1), we found that when shelter-in-place directives were not implemented, $\mathrm{PM}_{2.5}$ levels were constant across congregation density. However, when shelter-in-place directives were implemented, $\mathrm{PM}_{2.5}$ level had a positive relationship with religiosity $(\beta=0.4249, p<0.001)$. In other words, when shelter-in-place guidelines were implemented, increase in religiosity reduced the adherence to shelter-in-place directives (i.e., higher religiosity of a metropolitan area led to more activities contributing to elevated $\mathrm{PM}_{2.5}$ ).

To gain further insights and address the influence of other possible variables on adherence we conducted additional tests.

\section{Additional Tests}

Effect by religion. Our analysis has considered religions in aggregate; to further examine whether different religions reacted to COVID-19 guidelines differently, we repeat the analysis for each of the following majority denominations in the United States (Pew Forum, 2008): 
Evangelical, Mainline Protestant, Historically Black Protestant, Catholic, and religious minorities (Pew Forum, 2008). To accomplish this, we replaced the congregations per 10 thousand residents variable with a measure of the number of congregations, per denomination, per 10 thousand residents. We see a pattern similar to the previous analysis for Evangelical, Mainline Protestant, Historically Black Protestant, and Catholic denominations (see Table 2). Religious minority groups, including minority Christian and non-Christian denominations, exhibited the opposite pattern. Our findings add to research which suggests the attitudes and behaviors of adherents is heterogeneous across religions and denominations (Brammer et al., 2007; Hoffmann \& Miller, 1997; Mathras et al., 2016). Future research should consider the causes for varying adherence responses across religious groups.

Additional measures of religiosity. In order to obtain converging evidence with a measure other than congregational religious density, we replicated the analysis using two additional measures of religiosity: congregation reports of total adherents (Grammich et al., 2018) as well as a national, denomination-level self-report measure of the importance of religion in an individual's life (Pew Forum, 2008; see Supplemental Material D). The same pattern of results emerged showing an increase in religiosity was associated with a decrease in adherence when a state-issued shelter-in-place directive was implemented.

Political identity. Although a separation between religion and the state is codified in the Constitution of the United States, there is nevertheless a well-documented intertwining of religiosity and political conservatism (Duriez, 2003; Hirsh et al., 2013). In the United States, political conservatism is found to increase with religiosity, which is associated with an increased aversion to the curtailment of personal freedom (Young et al., 2013; Piazza, 2012; Thórisdóttir \& 
Jost, 2011). Therefore, one could question whether the response to COVID-19 guidelines is driven by religiosity or by political conservatism since conservative and liberal identities hold different beliefs about the severity of COVID -19 (Allcot et al., 2020).

To test this proposition we adopted a multi-pronged approach. First, we controlled for the dominant political identity of each metropolitan area in our model by considering majority party vote as well as the political party of the Governor. The county-level returns for the last five presidential elections (2000-2016; MIT Election Data and Science Lab, 2018) were used to calculate a ratio of total Republican candidate votes divided by total Democrat candidate votes. Thus, one indicates equal voting for Republican and Democrat candidates and a value greater (less) than one indicates a preference for Republican (Democratic) candidates. These countylevel ratios were then aggregated to the level of the metropolitan area using the method described previously. The results indicate that even after controlling for the political identity and the political party of the governor, the influence of religiosity on adherence remains significant (see Table 1, column four).

Second, while the interaction between majority party voting ratio and shelter-in-place directives is significant $(\beta=2.5208, \mathrm{p}<0.0023)$ when considered on its own, it is no longer a significant interaction ( $\beta=1.3263, p>0.05$ ) when considered with the interaction between religiosity and shelter-in-place directives $(\beta=0.3149, p=0.0447$; see Supplemental Material E).

Third, it is possible that an imbalance in the metropolitan areas (e.g., the inclusion of more majority Democrat voting cities) could skew the results reported. To address this possibility we created a dummy variable that represented each metropolitan area as either majority Republican voting or majority Democrat voting. We found that majority voting did not interact 
with religiosity and the issuance of a state-wide shelter-in-place directive. This further provides the insight that the interaction between religiosity and the issuance of a state-wide shelter-inplace directive does not differ across metropolitan areas based on majority political party alignment. Finally, the political party of the state's governor did not interact with religiosity and state-issued shelter-in-place orders (see Supplemental Material E). This last interaction, and the influence of the party of the governor in general, may be diminished by state-residents overwhelmingly preferring the response of their governor to that of the president and federal government (Blake, 2020; Crew et al., 2002).

These results align with recent research showing that religiosity and political conservatism might have a distinct influence on COVID-19 responses. For instance, adherenceencouraging tweets from state governors were associated with a reduction of mobility in both majority conservative and majority liberal communities, though the effect was more pronounced in majority liberal communities (Grossman et al., 2020). Similarly, in the initial period of the COVID -19 pandemic, prosocial framing had a significant impact on responsiveness to messaging (Jordan et al., 2020) when it is known that religiosity and prosocial behavior tend to be positively associated but the association of conservatism and prosocial behavior may be inconsistent (Pichon et al., 2007; Sagolou et al., 2005). More religious individuals reported stronger behavioral intentions towards following COVID -19 guidelines, while white, male, conservatives reported weaker behavioral intentions (Everett et al., 2020). Finally, belief in science is positively correlated with adherence to social distancing guidelines across both conservative and liberal areas (Brzezinski et al., 2020; McPhetres et al., 2020). 
Extending the date range. Finally, we consider an expanded date range that extends from February 15, 2020 through May 28, 2020. By extending the time period under consideration, we allow for the inclusion of states that were slower to implement shelter-in-place directives and metropolitan areas that were slower to respond to directives and recommendations. We also allow for the repeal of shelter-in-place directives. In our extended sample, 50 of the 53 metropolitan areas were covered by a state-issued shelter-in-place directive. In addition, 25 of municipalities had a state-issued shelter-in-place directive removed during the extended time period. Since results are again consistent across models, only those of the two-way random effects analysis are reported. Both the issuance of a state-ordered shelter-in-place order ( $\beta=$ 1.8446, $\mathrm{p}<0.0001)$ and the removal of such an order $(\beta=-2.1655, \mathrm{p}<0.0001)$ are associated with a decrease in $\mathrm{PM}_{2.5}$ levels (see Supplemental Material F). While this may seem counterintuitive, it can be understood based on two phenomenon. First, in many metropolitan areas, reopening after shelter-in-place orders has been phased, such that the state first removes its directive, and the city subsequently decides to what extent, if any, it will allow activities to resume. Thus, the removal of the state-level directive cannot be seen as the removal of all restrictions. Second, it is likely that the period of sheltering-in-place has encouraged a new set of behaviors among residents, which may take time to return. Future research should consider the change in activity over a longer period of time to estimate this response function.

The coefficient for the unemployment rate is negative and significant $(\beta=-0.0315, \mathrm{p}=$ 0.0345), suggesting that as unemployment increased in a metropolitan area, the amount of activity decreased. We again find a positive interaction between religiosity and state-issued 
shelter-in-place directives ( $\beta=0.0887, p=0.0041)$ and also an interaction between religiosity and the removal of such a directive $(\beta=0.1496, p=0.0039)$.

\section{Conclusions and Implications}

People turn to religion in times of calamities; our aim was to examine the impact of religiosity on mitigation policies for COVID-19. Our findings support the predictions of an established stream of literature, which predicts reactance against restrictions of personal and religious freedom, rather than rule adherence. We find that because precautions to curb the spread of the pandemic require one to avoid religious gatherings, such precautions can appear as a restriction against one's religious freedom. Specifically, our results indicate that higher religiosity results in an increase in movement when a shelter-in-place order has been made than when there is no such directive. This implies reactance to such state-issued mandates among communities with greater religiosity.

Theoretically, our findings have substantial implications for how religiosity interacts with other variables. Although individuals with greater religiosity are perceived to be more compliant with rules, in some instances religiosity can have a reactionary influence if the perception of the restriction of religious freedom is enhanced. This becomes problematic when such reactance endangers the health and well-being of the community. Understanding these contradictory scenarios is very helpful since it could inform policies and communications to help curb counterproductive or reactionary behavior.

COVID-19 directives provide a unique situation where behaviors intended to curb the spread of a pandemic requires one to avoid religious gatherings and meeting religious leaders who may provide support and solace (Wilson et al., 2020). Knowing and understanding the 
diverse ways the same directive can be perceived (e.g., as a precaution to curb spread or a restriction against religious practices) can increase the effectiveness of communication.

Our findings contribute to a growing body of research that explores the behavioral differences driven by religious beliefs as compared to those influenced by religious affiliation. For example, past research has found that collective commitment overshadows selective incentives for taking an action as a function of attendance at religious gatherings, but was not related to individual worship (Ginges et al., 2009). Similarly, people exhibited more helping behavior or fewer in-group preferences when primed with God than with a religious institution or religious leader (Ginges et al., 2016; Preston \& Ritter, 2013). Therefore, if a policy primes religious individuals to focus on community aspects of their religion, it may inadvertently reinforce commitments to the religious community while at the same time shifting attention to the needs of that in-group and reducing motivation to help the larger community.

Finally, prior research suggests that although calamities elicit the need for people to offer thoughts and prayers (e.g., through social gatherings and public displays) such acts may not be equally valued by all in the community, and in the extreme, may obstruct actual mitigation (Bentzen, 2020; Thunström, 2020; Thunström \& Noy, 2019). Our findings add to this research by showing that, during a pandemic and possibly because of the increased salience of religion during such a time, religious individuals react against directives that restrict religious gatherings. This contradicts the prediction that a focus on individual faith should increase helping behavior and reduce antagonism toward policies focused on the greater good (Everett et al., 2020; Jordan et al., 2020; Thunström et al., 2020). In this way, our research demonstrates that the influence of 
religiosity is more nuanced: specific policy decisions (e.g., shelter-in-place) moderates the influence of religiosity on the greater good.

Our research finds that, at the level of the metropolitan area, communities with higher religious density increased their activity after state-issued shelter-in-place directives were instituted, demonstrating a contradiction of or reactance to these directives. However, it is important to note that the specific motivations of individuals in these communities are not modeled. Thus, it is possible that the reactance behavior was caused by mistrust in the state or federal government, mistrust of science (Brzezinski et al., 2020; McPhetres et al., 2020), more extensive caregiving responsibilities among members of religious communities, or varying conceptualizations of "god as protector" or fears of divine punishment (Shariff \& Norenzayan, 2011). Future research should explore these individual-level attitudes and differences to develop a more nuanced understanding of the mechanisms that contribute to community level reactions.

While our research makes an important contribution to designing and assessing current COVID-19 mitigation strategies, it may also inform policy makers as they prepare for subsequent waves of COVID-19 and future calamities. First, because individuals respond to directives in different ways, some might react counter-productively. Understanding how messaging can be perceived as contradicting personal (e.g., religious) freedom can help policy makers re-frame messages. Second, because religiosity can affect whether the same directive is perceived as helpful or restrictive, understanding of the religious beliefs and practices of constituents can help local policy makers communicate with and educate people in their community. Such positive communication may reduce reactance against directives. Third, a directive to mitigate a public health threat may succeed if it is framed as helping others (which 
tends to align with religious guidelines) rather than restricting personal behaviors. Emphasizing the importance of adherence to the health and well-being of communities to which constituents share a strong sense of identity or sense of self, as opposed to appealing to a generalized sense of greater good, may help to engage a latent impulse to lend a hand, regardless of religious convictions. 


\section{References}

Ai, A. L., Cascio, T., Santangelo, L. K., \& Evans-Campbell, T. (2005). Hope, meaning, and growth following the September 11, 2001, terrorist attacks. Journal of Interpersonal Violence, 20(5), 523-548.

Allcott, H., Boxell, L., Conway, J., Gentzkow, M., Thaler, M., \& Yang, D. Y. (2020). Polarization and public health: Partisan differences in social distancing during the Coronavirus pandemic. NBER Working Paper, (w26946). Retrieved from https://ssrn.com/abstract=3574415

Arabi, Y. M., Murthy, S., \& Webb, S. (2020). COVID-19: A novel coronavirus and a novel challenge for critical care. Intensive Care Medicine, 46, 833-836.

Aschwanden, C. (2020). How 'superspreading' events drive most COVID-19 spread. Scientific American. Retrieved from https://www.scientificamerican.com/article/how-ldquosuperspreading-rsquo-events-drive-most-covid-19-spread/

Aukst-Margeti, B., \& Margeti, B. (2005). Religiosity and health outcomes: Review of literature. Collegium Antropologicum, 29(1), 365-371.

Bentzen, J. (2020). In crisis, we pray: Religiosity and the COVID-19 pandemic. SSRN Scholarly Paper ID 3615587. Retrieved from https://papers.ssrn.com/abstract=3615587

Blake, A. (2020). 49 of 50 governors have better coronavirus poll numbers than Trump. Washington Post. Retrieved from https://www.washingtonpost.com/politics/2020/05/19/49-50-governors-have-bettercoronavirus-numbers-than-trump 
Borgonovi, F. (2008). Divided we stand, united we fall: Religious pluralism, giving, and volunteering. American Sociological Review, 73(1), 105-128.

Brammer, S., Williams, G., \& Zinkin, J. (2007). Religion and attitudes to corporate social responsibility in a large cross-country sample. Journal of Business Ethics, 71(3), 229243.

Brenner, P. S. (2011). Exceptional behavior or exceptional identity? Overreporting of church attendance in the U.S. Public Opinion Quarterly, 75(1), 19-41.

Brenner, P. S. (2014). Testing the veracity of self-reported religious practice in the Muslim World. Social Forces, 92(3), 1009-1037.

Brown, D. R., \& Gary, L. E. (1994). Religious involvement and health status among AfricanAmerican males. Journal of the National Medical Association, 86(11), 825-831.

Brzezinski, A., Kecht, V., Van Dijcke, D., \& Wright, A. L. (2020). Belief in science influences physical distancing in response to COVID-19 lockdown policies. University of Chicago, Becker Friedman Institute for Economics Working Paper No. 2020-56. Retrieved from https://ssrn.com/abstract=3587990

Buuren, S., \& Groothuis-Oudshoorn, K. (2011). mice: Multivariate imputation by chained equations in R. Journal of Statistical Software, 45(1), 1-67.

Centers for Disease Control and Prevention. (2020). CDC, Washington State report first COVID19 death. Retrieved from https://www.cdc.gov/media/releases/2020/s0229 -COVID-19first-death.html

Crew Jr, R. E., Branham, D., Weiher, G. R., \& Bernick, E. (2002). Political events in a model of gubernatorial approval. State Politics \& Policy Quarterly, 2(3), 283-297. 
Cui, J., Jo, H., \& Velasquez, M. G. (2015). The influence of christian religiosity on managerial decisions concerning the environment. Journal of Business Ethics, 132(1), 203-231.

Cunningham, A. C., Goh, H. P., \& Koh, D. (2020). Treatment of COVID-19: Old tricks for new challenges. Critical Care, 24(1), 91.

Desmond, S. A., Ulmer, J. T., \& Bader, C. D. (2013). Religion, self control, and substance use. Deviant Behavior, 34(5), 384-406.

Djupe, P. A., Neiheisel, J. R., \& Conger, K. H. (2018). Are the politics of the christian right linked to state rates of the nonreligious? The importance of salient controversy. Political Research Quarterly, 71(4), 910-922.

Donnermeyer, J., Anderson, C., \& Cooksey, E. (2019). The Amish population: County estimates and settlement patterns. Journal of Amish and Plain Anabaptist Studies, 1(1), 72-109.

Duriez, B. (2003). Religiosity and conservatism revisited: Relating a new religiosity measure to the two main conservative political ideologies. Psychological Reports, 92(2), 533-539.

Everett, J. A. C., Colombatto, C., Chituc, V., Brady, W. J., \& Crockett, M. (2020). The effectiveness of moral messages on public health behavioral intentions during the COVID-19 pandemic [Preprint]. PsyArXiv. https://doi.org/10.31234/osf.io/9yqs8

Fox, J., \& Tabory, E. (2008). Contemporary evidence regarding the impact of state regulation of religion on religious participation and belief. Sociology of Religion, 245-271.

Fukuyama, Y. (1961). The major dimensions of church membership. Review of Religious Research, 2(4), 154-161.

Gecewicz, C. (2020). Few Americans say their house of worship is open, but a quarter say their faith has grown amid pandemic. Pew Research Center. Retrieved from 
https://www.pewresearch.org/fact-tank/2020/04/30/few-americans-say-their-house-ofworship-is-open-but-a-quarter-say-their-religious-faith-has-grown-amid-pandemic/

Ginges, J., Hansen, I., \& Norenzayan, A. (2009). Religion and support for suicide attacks. Psychological Science, 20(2), 224-230.

Ginges, J., Sheikh, H., Atran, S., \& Argo, N. (2016). Thinking from God’s perspective decreases biased valuation of the life of a nonbeliever. Proceedings of the National Academy of Sciences, 113(2), 316-319.

Gorsuch, R. L. (1984). Measurement: The boon and bane of investigating religion. American Psychologist, 39(3), 228-236.

Grammich, C., Hadaway, K., Houseal, R., Jones, D., Krindatch, A., Stanley, R., \& Taylor, R. (2018). U.S. religion census: Religious congregations and membership study, 2010 (county file). Retrieved from https://osf.io/qun29/

Grossman, G., Kim, S., Rexer, J., \& Thirumurthy, H. (2020). Political partisanship influences behavioral responses to governors' recommendations for COVID-19 prevention in the United States. SSRN Scholarly Paper ID 3578695. Retrieved from https://ssrn.com/abstract=3578695

Guéguen, N., Bougeard-Delfosse, C., \& Jacob, C. (2015). The positive effect of the mere presence of a religious symbol on compliance with an organ donation request. Social Marketing Quarterly, 21(2), 92-99.

Hall, D. E., Meador, K. G., \& Koenig, H. G. (2008). Measuring religiousness in health research: Review and critique. Journal of Religion and Health, 47(2), 134-163. 
Harrison, G. W., \& List, J. A. (2004). Field experiments. Journal of Economic literature, 42(4), 1009-1055.

Hill, P. C., \& Edwards, E. (2013). Measurement in the psychology of religiousness and spirituality: Existing measures and new frontiers. In K. I. Pargament, J. J. Exline, \& J. W. Jones (Eds.), APA handbook of psychology, religion, and spirituality (Vol. 1): Context, theory, and research (p. 51-77). American Psychological Association.

Hill, P. C., Pargament, K. I., Hood, R. W., McCullough, J., Michael E., Swyers, J. P., Larson, D. B., Zinnbauer, B. J. (2000). Conceptualizing religion and spirituality: Points of commonality, points of departure. Journal for the Theory of Social Behaviour, 30(1), 5177.

Hirsh, J. B., Walberg, M. D., \& Peterson, J. B. (2013). Spiritual liberals and religious conservatives. Social Psychological and Personality Science, 4(1), 14-20.

Hoffmann, J. P., \& Miller, A. S. (1997). Social and political attitudes among religious groups: Convergence and divergence over time. Journal for the Scientific Study of Religion, 36(1), 52-70.

Holdcroft, B. B. (2006). What is religiosity. Catholic Education: A Journal of Inquiry and Practice, 10(1), 89-103.

Hsiao, C. (2014). Analysis of panel data. New York, NY: Cambridge University Press.

Iyer, S. (2016). The new economics of religion. Journal of Economic Literature, 54(2), 395-441.

Jordan, J., Yoeli, E., \& Rand, D. G. (2020). Don’t get it or don’t spread it? Comparing selfinterested versus prosocially framed COVID-19 prevention messaging [Preprint]. PsyArXiv. https://doi.org/10.31234/osf.io/yuq7x 
Kane, M. D. (2013). LGBT religious activism: Predicting state variations in the number of metropolitan community churches, 1974-2000. Sociological Forum, 28(1), 135-158.

Laird, R. D., Marks, L. D., \& Marrero, M. D. (2011). Religiosity, self-control, and antisocial behavior: Religiosity as a promotive and protective factor. Journal of Applied Developmental Psychology, 32(2), 78-85.

Lechner, M. (2011). The estimation of causal effects by difference-in-differences methods. Foundations and Trends R in Econometrics, 4(3), 165-224.

List, J. A. (2007). Field experiments: a bridge between lab and naturally occurring data. The $B E$ Journal of Economic Analysis \& Policy, 6(2).

Markstrom, C. A. (1999). Religious involvement and adolescent psychosocial development. Journal of Adolescence, 22(2), 205-221.

Mathras, D., Cohen, A. B., Mandel, N., \& Mick, D. G. (2016). The effects of religion on consumer behavior: A conceptual framework and research agenda. Journal of Consumer Psychology, 26(2), 298-311.

McBride, M. (2008). Religious pluralism and religious participation: A game theoretic analysis. American Journal of Sociology, 114(1), 77-106.

McClure, J. M. (2017). Go and do likewise: Investigating whether involvement in congregationally sponsored community service activities predicts prosocial behavior. Review of Religious Research, 59(3), 341-366.

McCullough, M. E., Hoyt, W. T., Larson, D. B., Koenig, H. G., \& Thoresen, C. (2000). Religious involvement and mortality: A meta-analytic review. Health Psychology, 19(3), 211-222. 
McPhetres, J., Jong, J., \& Zuckerman, M. (2020). Religious Americans have less positive attitudes toward science, but this does not extend to other cultures. Social Psychological and Personality Science, Advanced online publication.

Meyer, B. D. (1995). Natural and quasi-experiments in economics. Journal of Business \& Economic Statistics, 13(2), 151-161.

MIT Election Data and Science Lab. (2018). County presidential election returns 2000-2016. Harvard Dataverse. Retrieved from https://dataverse.harvard.edu/dataset.xhtml? persistentId=doi:10.7910/DVN/VOQCHQ

Osheim, D. J. (2008). Religion and epidemic disease. Historically Speaking, 9(7), 36-37.

Pew Forum. (2008). U.S. religious landscape survey. Retrieved from https:/www.pewforum.org/ religious-landscape-study/

Piazza, J. (2012). If you love me keep my commandments: Religiosity increases preference for rule-based moral arguments. The International Journal for the Psychology of Religion, 22(4), 285-302.

Pichon, I., Boccato, G., \& Saroglou, V. (2007). Nonconscious influences of religion on prosociality: A priming study. European Journal of Social Psychology, 37(5), 1032-1045.

Poulin, M. J., Silver, R. C., Gil-Rivas, V., Holman, E. A., \& McIntosh, D. N. (2009). Finding social benefits after a collective trauma: Perceiving societal changes and well-being following 9/11. Journal of Traumatic Stress: Official Publication of The International Society for Traumatic Stress Studies, 22(2), 81-90.

Preston, J. L., \& Ritter, R. S. (2013). Different effects of religion and God on prosociality with the ingroup and outgroup. Personality and Social Psychology Bulletin, 39(11), 1471-1483 
Rossi, M., \& Scappini, E. (2014). Church attendance, problems of measurement, and interpreting indicators: A study of religious practice in the United States, 1975-2010. Journal for the Scientific Study of Religion, 53(2), 249-267.

Saroglou, V., Corneille, O., \& Van Cappellen, P. (2009). "Speak, Lord, your servant is listening”: Religious priming activates submissive thoughts and behaviors. The International Journal for the Psychology of Religion, 19(3), 143-154.

Saroglou, V., Pichon, I., Trompette, L., Verschueren, M., \& Dernelle, R. (2005). Prosocial behavior and religion: New evidence based on projective measures and peer ratings. Journal for the Scientific Study of Religion, 44(3), 323-348.

Scala, D. J., \& Johnson, K. M. (2017). Political polarization along the rural-urban continuum? The geography of the presidential vote, 2000-2016. The ANNALS of the American Academy of Political and Social Science, 672(1), 162-184.

Schuster, M. A., Stein, B. D., Jaycox, L. H., Collins, R. L., Marshall, G. N., Elliott, M. N., ... \& Berry, S. H. (2001). A national survey of stress reactions after the September 11, 2001, terrorist attacks. New England Journal of Medicine, 345(20), 1507-1512.

Shariff, A. F., \& Norenzayan, A. (2011). Mean gods make good people: Different views of God predict cheating behavior. The International Journal for the Psychology of Religion, 21(2), 85-96.

Smith, I., Sawkins, J. W., \& Seaman, P. T. (1998). The economics of religious participation: A cross-country study. Kyklos, 51(1), 25-44. 
Snell, S. A. (2014). The social influence of religious congregation on political behavior. [Doctoral dissertation, Princeton University]. Retrieved from http://arks.princeton.edu/ark:/88435/dsp01j098zd33r

The Associated Press. (2020). Judge: Kentucky church can conduct Easter drive-in service. The New York Times. Retrieved 2020-04-19, from https://apnews.com/28cb3aeb9345392f336b77e4b3da5bf3

Thunström, L. (2020). Thoughts and prayers - Do they crowd out charity donations? Journal of Risk and Uncertainty, 60(1), 1-28.

Thunström, L., Ashworth, M., Shogren, J. F., Newbold, S., \& Finnoff, D. (2020). Testing for COVID-19: Willful ignorance or selfless behavior? Behavioural Public Policy, 1-18.

Thunström, L., \& Noy, S. (2019). The value of thoughts and prayers. Proceedings of the National Academy of Sciences, 116(40), 19797-19798.

Thurston, G. D., Ito, K., \& Lall, R. (2011). A source apportionment of US fine particulate matter air pollution. Atmospheric Environment, 45(24), 3924-3936.

Thórisdóttir, H., \& Jost, J. T. (2011). Motivated closed-mindedness mediates the effect of threat on political conservatism. Political Psychology, 32(5), 785-811.

Torabi, M. R., \& Seo, D. C. (2004). National study of behavioral and life changes since September 11. Health Education \& Behavior, 31(2), 179-192.

Torgler, B. (2006). The importance of faith: Tax morale and religiosity. Journal of Economic Behavior \& Organization, 61(1), 81-109. 
Running Head: RELIGION AND COVID-19 MITIGATION

University of Wisconsin Public Health Institute. (2020). County health rankings model: Social associations. County Health Rankings \& Roadmaps. Retrieved from https://www.countyhealthrankings.org

U.S. Census Bureau. (2019a). American Community Survey Data Releases. The United States Census Bureau. Retrieved from https://www.census.gov/programs-surveys/acs/news/data-releases.html

U.S. Census Bureau. (2019b). SAIPE State and County Estimates for 2018. The United States Census Bureau. Retrieved from https://www.census.gov/data/datasets/2018/demo/saipe/2018-state-and-county.html

U.S. Census Bureau. (2020). County Population Totals: 2010-2019. The United States Census Bureau. Retrieved from https://www.census.gov/data/datasets/time-series/demo/popest/2010s-counties-total.html

U.S. Department of Labor. (2020). Unemployment Insurance Weekly Claims Data, Employment \& Training Administration (ETA). The United States Department of Labor. Retrieved from https://oui.doleta.gov/unemploy/claims.asp

Van Cappellen, P., Corneille, O., Cols, S., \& Saroglou, V. (2011). Beyond mere compliance to authoritative figures: Religious priming increases conformity to informational influence among submissive people. The International Journal for the Psychology of Religion, 21(2), 97-105. 
Williams, D. R., Larson, D. B., Buckler, R. E., Heckmann, R. C., \& Pyle, C. M. (1991). Religion and psychological distress in a community sample. Social Science \& Medicine, 32(11), $1257-1262$.

Williams, J. T. B., \& O’Leary, S. T. (2019). Denver religious leaders’ vaccine attitudes, practices, and congregational experiences. Journal of Religion and Health, 58(4), 1356-1367.

Wilson, S., Boorstein, M., \& Hernández, A. R. (2020). Coronavirus creates conflict for churches, where gatherings can be dangerous but also provide solace. Retrieved from https://www.washingtonpost.com/national/coronavirus-church-services-outbreak/ 2020/04/05/7f5b63cc-7773-11ea-90ad -819caa48d39f story.html

Wing, C., Simon, K., \& Bello-Gomez, R. A. (2018). Designing difference in difference studies: Best practices for public health research. Annual Review of Public Health, 39(1), 453469.

Wu, E. C., \& Cutright, K. M. (2018). In God's hands: How reminders of God dampen the effectiveness of fear appeals. Journal of Marketing Research, 55(1), 119-131.

Yadav, R., Beig, G., \& Jaaffrey, S. N. A. (2014). The linkages of anthropogenic emissions and meteorology in the rapid increase of particulate matter at a foothill city in the Arawali range of India. Atmospheric Environment, 85, 147-151.

Young, A., Olga, Willer, R., \& Keltner, D. (2013). Thou shalt not kill: Religious fundamentalism, conservatism, and rule-based moral processing. Psychology of Religion and Spirituality, 5(2), 110-115. 
Zalakeviciute, R., López-Villada, J., \& Rybarczyk, Y. (2018). Contrasted effects of relative humidity and precipitation on urban $\mathrm{PM}_{2.5}$ pollution in high elevation urban areas. Sustainability, 10(6), 2064. 
Table 1.

Regression results including the base model, control variables, and political identity controls.

\begin{tabular}{|c|c|c|c|}
\hline Variable & $\begin{array}{l}\text { Base Model } \\
\qquad \beta \\
\text { (SE) }\end{array}$ & $\begin{array}{c}\text { Base }+ \text { Controls } \\
\beta \\
(\mathrm{SE})\end{array}$ & $\begin{array}{c}\text { Base }+ \text { Controls }+ \\
\text { Political Identity } \\
\beta \\
(\mathrm{SE})\end{array}$ \\
\hline Intercept & $\begin{array}{l}6.0232^{* * *} \\
(0.7749)\end{array}$ & $\begin{array}{c}9.8891 \\
(10.6457)\end{array}$ & $\begin{array}{c}10.0066 \\
(12.8258)\end{array}$ \\
\hline COVID cases confirmed & & $\begin{array}{l}-0.0002 \\
(0.0008)\end{array}$ & $\begin{array}{l}-0.0002 \\
(0.0008)\end{array}$ \\
\hline COVID deaths & & $\begin{array}{l}-0.0006 \\
(0.0243)\end{array}$ & $\begin{array}{l}-0.0006 \\
(0.0244)\end{array}$ \\
\hline Precipitation & & $\begin{array}{c}-0.0042^{* * *} \\
(0.001)\end{array}$ & $\begin{array}{c}-0.0042^{* * *} \\
(0.001)\end{array}$ \\
\hline Five year $\mathrm{PM}_{2.5}$ average & & $\begin{array}{c}-0.0226 \\
(0.0413)\end{array}$ & $\begin{array}{l}-0.0226 \\
(0.0413)\end{array}$ \\
\hline Day of the week & & $\begin{array}{c}0.016 \\
(0.0974)\end{array}$ & $\begin{array}{c}0.016 \\
(0.0975)\end{array}$ \\
\hline Bachelor's degree attainment & & $\begin{array}{c}-0.0174 \\
(0.1509)\end{array}$ & $\begin{array}{l}-0.0199 \\
(0.1862)\end{array}$ \\
\hline Unemployment & & $\begin{array}{l}-0.2316 \\
(0.2445)\end{array}$ & $\begin{array}{l}-0.2331 \\
(0.2449)\end{array}$ \\
\hline Poverty rate & & $\begin{array}{c}-0.0443 \\
(2.9775)\end{array}$ & $\begin{array}{c}-0.0397 \\
(0.4392)\end{array}$ \\
\hline Social membership groups & & $\begin{array}{c}0.0004 \\
(0.0009)\end{array}$ & $\begin{array}{c}0.0005 \\
(0.0009)\end{array}$ \\
\hline Political party of governor & & & $\begin{array}{l}-0.1746 \\
(1.5354)\end{array}$ \\
\hline Majority party voting ratio & & & $\begin{array}{c}-0.1622 \\
(3.3079)\end{array}$ \\
\hline Congregations per $10 \mathrm{k}$ residents & & $\begin{array}{c}-0.0187 \\
(0.2756)\end{array}$ & $\begin{array}{c}-0.0007 \\
(0.3508)\end{array}$ \\
\hline State-level shelter-in-place directive & $\begin{array}{c}-4.0587^{* * *} \\
(0.9115)\end{array}$ & $\begin{array}{c}-3.6931^{* * *} \\
(0.9793)\end{array}$ & $\begin{array}{c}-3.6941^{* * *} \\
(0.9799)\end{array}$ \\
\hline $\begin{array}{l}\text { State-level shelter-in-place X Religious } \\
\text { congregations } \\
R^{2}\end{array}$ & $\begin{array}{l}0.4607^{* * *} \\
(0.1221) \\
0.01651\end{array}$ & $\begin{array}{l}0.4249^{* * *} \\
(0.1275) \\
0.0287\end{array}$ & $\begin{array}{c}0.4251^{* * *} \\
(0.1275) \\
0.0287\end{array}$ \\
\hline$x^{2}$ & $26.625^{* * *}$ & $46.3355^{* * *}$ & $46.2929^{* *}$ \\
\hline
\end{tabular}


Table 2

Effect by religious denomination.

\begin{tabular}{|c|c|c|c|c|c|}
\hline Variable & $\begin{array}{c}\text { Evangelical } \\
\beta \\
\text { (SE) }\end{array}$ & $\begin{array}{c}\text { Mainline } \\
\text { Protestant } \\
\beta \\
(\mathrm{SE})\end{array}$ & $\begin{array}{c}\text { Historically } \\
\text { Black } \\
\text { Protestant } \\
\beta \\
(\mathrm{SE})\end{array}$ & $\begin{array}{l}\text { Catholic } \\
\qquad \beta \\
(\mathrm{SE})\end{array}$ & $\begin{array}{c}\text { Religious } \\
\text { Minority } \\
\beta \\
(\mathrm{SE})\end{array}$ \\
\hline Intercept & $\begin{array}{c}5.6223 \\
(3.9023)\end{array}$ & $\begin{array}{c}6.3961 \\
(4.4666)\end{array}$ & $\begin{array}{c}6.2294 \\
(23.1969)\end{array}$ & $\begin{array}{c}6.9196 \\
(3.8719)\end{array}$ & $\begin{array}{l}7.4675^{*} \\
(3.5544)\end{array}$ \\
\hline Evangelical & $\begin{array}{c}0.3155 \\
(0.7628)\end{array}$ & & & & \\
\hline Mainline Protestant & & $\begin{array}{c}0.3979 \\
(2.2968)\end{array}$ & & & \\
\hline Historically Black & & & 1.6366 & & \\
\hline Protestant & & & (30.4452) & & \\
\hline Catholic & & & & $\begin{array}{c}0.3092 \\
(6.2554)\end{array}$ & \\
\hline Religious Minority & & & & & $\begin{array}{l}-0.3388 \\
(1.6502)\end{array}$ \\
\hline $\begin{array}{l}\text { State-level shelter-in- } \\
\text { place directive }\end{array}$ & $\begin{array}{l}-3.062^{* * *} \\
(0.6602)\end{array}$ & $\begin{array}{l}-1.8329^{* * *} \\
(0.5031)\end{array}$ & $\begin{array}{l}-2.0167^{* * *} \\
(0.4313)\end{array}$ & $\begin{array}{l}-1.3532 \\
(0.5065)\end{array}$ & $\begin{array}{l}3.1116^{* * *} \\
(0.758)\end{array}$ \\
\hline $\begin{array}{l}\text { State-level shelter-in- } \\
\text { place X Denomination }\end{array}$ & $\begin{array}{l}0.6472^{* * *} \\
(0.1678)\end{array}$ & $\begin{array}{l}0.6994^{* *} \\
(0.2706)\end{array}$ & $\begin{array}{l}3.8903^{* * *} \\
(1.0282)\end{array}$ & $\begin{array}{c}1.0769 \\
(0.7455)\end{array}$ & $\begin{array}{c}-3.8117^{* * *} \\
(0.705)\end{array}$ \\
\hline$R^{2}$ & 0.0141 & 0.0089 & 0.0136 & 0.0042 & 0.0228 \\
\hline$x^{2}$ & $22.67^{* * *}$ & $14.2496^{* *}$ & $21.8919^{* * *}$ & $9.6206^{*}$ & $36.9162^{* * *}$ \\
\hline
\end{tabular}




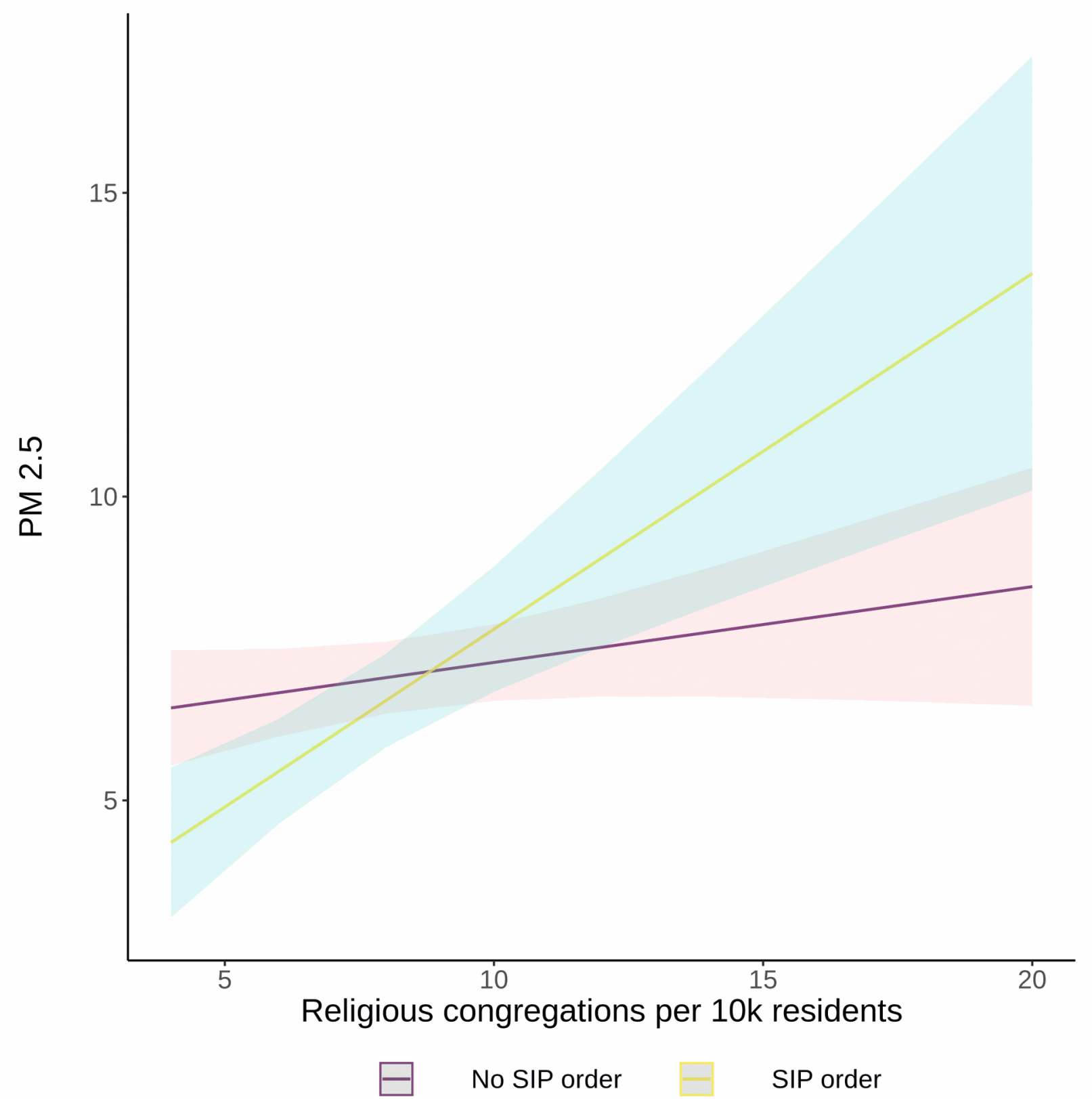

Figure 1. The marginal effects of the interaction between the number of religious congregations per 10 thousand residents and state-issued shelter-in-place (SIP) orders on $\mathrm{PM}_{2.5}$. 
Running Head: RELIGION AND COVID-19 MITIGATION SUPPLEMENT

\section{Supplemental Material A: Data and Variables}

The metropolitan statistical areas (hereafter referred to as metropolitan areas) used in this project originate from the 2010 U.S. Census (U.S. Census Bureau, 2010). A metropolitan area is an urban area with a population of at least 50,000 residents, along with the surrounding counties whose residents regularly commute into the urban center. We selected the top 53 metropolitan areas, whose populations are estimated to be over 1,000,000 people. The county-level data in this project were aggregated to their respective metropolitan area using a population-weighted mean. Summary statistics are reported in Table A1.

Adherence. Hourly pollution data was collected from the EPA website through the public API. Although there are various types of pollution data available, local vehicle emissions are best represented through $\mathrm{PM}_{2.5}$, representing particulate matter with diameter less than 2.5

micrometers, which are released as a byproduct of fuel combustion and transportation. Data were collected hourly, and the mean pollution for each day, between 0:00 and 23:59 GMT, was calculated for each metropolitan area (U.S. Environmental Protection Agency, 2020). Dallas, Houston, Orlando, San Antonio, and Austin each did not report one to two days of $\mathrm{PM}_{2.5}$ data. Missing data was imputed as described in the main article. In addition, the five-year average for each metropolitan area, for each day was calculated.

Religiosity. Religious density data was collected from the 2010 U.S. Religion Census, conducted by the Association of Statisticians of American Religious Bodies, and provided by the Association of Religious Data Archives. The census reports county-level counts of the number of adherents and congregations for each of 236 faith groups (Grammich et al., 2018). For the additional analysis in this supplement, the data was augmented with the results of a national 
survey of religious attitudes (Pew Forum, 2008). Specifically, for each denomination, the percentage of respondents claiming religion is "very important" in their lives is multiplied by the number of reported adherents of that denomination, in each county. This provides a rough estimate of the overall perception that religion is "very important" in the lives of residents of each county.

Shelter-in-place directives. Because shelter-in-place directives have been given various names across the United States, for the purposes of our analysis any statewide order that restricts movement was tagged as a shelter-in-place directive regardless of the particular name it was given (e.g., "stay at home,” "safer at home”). The date of each directive was collected by searching state and city news sources.

COVID-19 prevalence. County-level COVID-19 infection and death rates were collected from Johns Hopkins University (Dong et al., 2020).

Weather. Weather data was collected from the National Oceanic and Atmospheric Administration. One weather station was selected from each metropolitan area only if it recorded average wind speed, maximum temperature, and precipitation for each day from January 1, 2020 through April 1, 2020 (Menne et al., 2020).

Political identity. The majority political alignment of each metropolitan area was determined through county-level election returns from each presidential election from 2000 through 2016 (MIT Election Data and Science Lab, 2018). Since several districts, including those in our 53 metropolitan areas, changed voting patterns in 2016, using data from the previous five elections controls for shifts and anomalies. The political identity variable is calculated as a ratio of the total votes for the Republican candidate divided by the total votes for the Democrat 
candidate, for each county. Thus, a value equal to one represents even voting for both Republican and Democrat candidates. A value greater (less) than one indicates a preference for Republican (Democrat) candidates. Additionally, a majority vote variable was created, with one indicating a ratio greater than one (Republican preference) and zero indicating a ratio less than one (Democrat preference). In our sample, 17 metropolitan areas are majority Republican voting and 36 are majority Democrat voting.

Governor party. First, an indicator variable was created such that a value of one indicated that state's governor was a member of the Republican party and a zero indicated that state's governor was a member of the Democrat party. Since some metropolitan areas cross state lines, a variable was calculated based on the population-weighted mean of each state in each metropolitan area.

Region. Each metropolitan area was assigned to a region (e.g., New England, Middle Atlantic, East North Central, Mountain) based on its classification by the U.S. Census Bureau (2020).

Education, poverty, and unemployment. County-level bachelor's degree attainment rates were calculated from the American Community Survey (U.S. Census Bureau, 2019a) using a five-year average (2014-2018). County-level poverty rates were collected from the 2018 SAIPE estimate (U.S. Census Bureau, 2019b). Weekly state-level unemployment filings were compiled from (U.S. Department of Labor, 2020) and aggregated to each metropolitan area based on the population-weighted mean of each county in each state.

Social associations. A measure of social group activity was calculated via a county-level count of the total number of membership associations in a county in 2017, divided by the 
population of that county. This count includes civic, sports, fitness, religious, political, labor, business, and professional organizations (University of Wisconsin Public Health Institute, 2020).

Table A1

Summary statistics for the variables in our analysis.

\begin{tabular}{lccccc}
\hline & Mean & Std. dev. & Median & Min & Max \\
Main variables & & & & & \\
PM $_{2.5}$ & 6.9826 & 3.3303 & 6.3648 & 0.4505 & 25.4431 \\
Religious congregations per 10k residents & 8.5332 & 2.858 & 7.7494 & 4.0 & 18.9837 \\
Religious adherents per 10k residents & 47.8378 & 8.8468 & 49.6447 & 31.5748 & 73.9813 \\
Religious importance & 6.0883 & 2.1534 & 5.5902 & 2.9153 & 14.467 \\
Control variables & & & & & \\
COVID cases confirmed & 76.1837 & 258.1418 & 5.1652 & 0 & 4375.5769 \\
COVID deaths & 1.7702 & 8.2391 & 0 & 0 & 150.0599 \\
Precipitation & 27.3874 & 69.4076 & 0 & 0 & 831.0 \\
Five-year PM 2.5 average & 7.6424 & 2.3268 & 7.5257 & 2.2958 & 22.8483 \\
Majority voting ratio & 0.3962 & 0.4893 & 0 & 0 & 1 \\
Bachelor's degree attainment & 35.2152 & 6.2495 & 34.0019 & 21.0774 & 52.5821 \\
Poverty rate & 11.8451 & 2.6494 & 12.1049 & 6.2967 & 19.2915 \\
Unemployment & 1.3693 & 0.7818 & 1.193 & 0.37 & 6.1889 \\
Social associations & 857.6606 & 695.4665 & 674.3276 & 46.8087 & 4774.66 \\
\hline
\end{tabular}

\section{Supplemental Material B: Random, Fixed, and Fully Pooled Models}

Though conventional tests suggest that a two-way random effects model is preferred for our data (see discussion in main text) it may be useful to compare the results across two-way random effects, two-way fixed effects, and fully pooled OLS models (see Table A2).

Table A2

Regression results for random, fixed, and pooled effects models.

\begin{tabular}{lccc}
\hline & Random Effects & Fixed Effects & Pooled Effects \\
& $\beta$ & $\beta$ & $\beta$ \\
Variable & $(\mathrm{SE})$ & $(\mathrm{SE})$ & $(\mathrm{SE})$ \\
\hline & 10.0066 & & $7.8539^{* * *}$ \\
Intercept & $(12.8258)$ & & $(1.9573)$
\end{tabular}




\begin{tabular}{|c|c|c|c|}
\hline \multirow{3}{*}{ COVID cases confirmed } & -0.0002 & -0.0005 & 0.0006 \\
\hline & $(0.0008)$ & $(0.0008)$ & $(0.0007)$ \\
\hline & -0.0006 & 0.0077 & -0.0104 \\
\hline \multirow[t]{2}{*}{ COVID deaths } & $(0.0244)$ & $(0.0251)$ & $(0.0212)$ \\
\hline & $-0.0042^{* * *}$ & $-0.0043^{* * *}$ & $-0.0024^{*}$ \\
\hline \multirow[t]{2}{*}{ Precipitation } & $(0.001)$ & $(0.001)$ & $(0.0011)$ \\
\hline & -0.0226 & -0.0262 & 0.0509 \\
\hline \multirow{2}{*}{ Five year $\mathrm{PM}_{2.5}$ average } & $(0.0413)$ & $(0.0423)$ & $(0.0372)$ \\
\hline & 0.016 & & 0.011 \\
\hline \multirow[t]{2}{*}{ Day of the week } & $(0.0975)$ & & $(0.0372)$ \\
\hline & -0.0199 & & -0.0121 \\
\hline \multirow[t]{2}{*}{ Bachelor's degree attainment } & $(0.1862)$ & & $(0.0265)$ \\
\hline & -0.2331 & -0.3778 & 0.1462 \\
\hline \multirow[t]{2}{*}{ Unemployment } & $(0.2449)$ & $(0.2593)$ & $(0.1884)$ \\
\hline & -0.0397 & & -0.019 \\
\hline \multirow[t]{2}{*}{ Poverty rate } & $(0.4392)$ & & $(0.0626)$ \\
\hline & 0.0005 & & $0.0003^{*}$ \\
\hline \multirow[t]{2}{*}{ Social membership groups } & $(0.0009)$ & & $(0.0001)$ \\
\hline & -0.1746 & & -0.0473 \\
\hline \multirow[t]{2}{*}{ Political party of governor } & $(1.5354)$ & & $(0.2215)$ \\
\hline & -0.1622 & & -0.0911 \\
\hline \multirow[t]{2}{*}{ Majority party voting ratio } & $(3.3079)$ & & $(0.4661)$ \\
\hline & -0.0007 & & 0.0222 \\
\hline \multirow[t]{2}{*}{ Congregations per $10 \mathrm{k}$ residents } & $(0.3508)$ & & $(0.0495)$ \\
\hline & $-3.6941^{* * *}$ & $-3.5749^{* * *}$ & $-3.6187^{* * *}$ \\
\hline State-level shelter-in-place directive & $(0.9799)$ & $(0.9959)$ & $(1.0153)$ \\
\hline State-level shelter-in-place X Religious & $0.4251^{* * *}$ & $0.3946^{* *}$ & $0.4854^{* * *}$ \\
\hline congregations & $(0.1275)$ & $(0.1298)$ & $(0.1314)$ \\
\hline$R^{2}$ & 0.0287 & 0.0285 & 0.1991 \\
\hline$F$ & & $5.4962^{* * *}$ & $17.7026^{* * *}$ \\
\hline$x^{2}$ & $46.2929^{* *}$ & & \\
\hline
\end{tabular}

Note: $* p<0.05, * * p<0.01, * * * p<0.001$.

\section{Supplemental Material C: Assumption Tests}

We replicated these results by considering religiosity a categorical variable created via a median-split of the number of congregations per 10 thousand residents in our sample. Doing so conforms to a classical difference-in-differences paradigm and can make interpretation easier. This essentially results in a naturalistic 2(religiosity: high vs. low) x 2(shelter-in-place: directive enacted vs. directive not enacted) quasi-experiment. When we fit a simple model that tests the 
primary interaction alone, we found a significant interaction between high religiosity and the presence of a shelter-in-place directive ( $\beta=1.205, \mathrm{p}=0.0088$, see Table A2). When we fit a full model considering all control variables, again, we found a significant interaction between high religiosity and the presence of a shelter-in-place directive $(\beta=1.1747, \mathrm{p}=0.0167$; see Table 1$)$. This supports our conclusion that, for communities with a higher density of religious congregations, shelter-in-place directives had the opposing result of increasing vehicular movement.

Table A2

Results with a categorical religiosity variable.

\begin{tabular}{lcc}
\hline & Base Model & Base Model + Controls \\
Variable & $\beta$ & $\beta$ \\
\hline Intercept & $(\mathrm{SE})$ & $(\mathrm{SE})$ \\
COVID cases confirmed & $6.524^{* * *}$ & 9.5471 \\
& $(0.3894)$ & $(9.0414)$ \\
COVID deaths & & -0.0002 \\
& & $(0.0008)$ \\
Precipitation & -0.0037 \\
Five year PM 2.5 & $(0.025)$ \\
& & $-0.0041^{* * *}$ \\
Day of the week & & $(0.001)$ \\
& & -0.022 \\
Bachelor's degree attainment & & $(0.0413)$ \\
& & 0.0153 \\
Unemployment & & $(0.0984)$ \\
& -0.013 \\
Poverty rate & & $(0.1385)$ \\
Social membership groups & -0.2769 \\
& & $(0.2443)$ \\
Religiosity & & -0.0374 \\
& & $(0.3589)$ \\
State-level shelter-in-place & 0.0005 \\
& & $(0.0009)$ \\
& & -0.0375 \\
& & $(1.3077)$ \\
& & $-1.0382^{* *}$
\end{tabular}


directive

State-level shelter-in-place $\mathrm{X}$

Religiosity

$R^{2}$

$x^{2}$

Note: $* p<0.05, * * p<0.01, * * * p<0.001$.
(0.3156)

$1.1463^{*}$

$(0.4511)$

0.0139

$22.3057^{* * *}$
$(0.0 .3502)$

$1.1023^{*}$

(0.3502)

0.0259

$41.7145^{* *}$

The use of shelter-in-place directives as an intervention in a natural quasi-experiment assumes that the common trend assumption holds (Wing et al., 2018). While there is some debate as to the importance of this assumption for difference-in-differences analysis (Kahn-Lang \& Lang, 2019; Ryan et al., 2019), there is evidence that failure to carefully compare prior trends can produce confusing results (Jaeger et al., 2020). The common trend assumption for a difference-in-differences analysis assumes that the unmeasured variables are either timeinvariant group features of time-varying features that are group invariant. Therefore, we examine whether the groups (e.g., with religiosity high vs. low) exhibit common trends (captured graphically via parallel trends) prior to the intervention (Wing et al., 2018). For instance, is it possible that in March, metropolitan areas low in religiosity have higher $\mathrm{PM}_{2.5}$ levels compared to February, while this pattern reversed in metropolitan areas high in religiosity? If such a pattern exists, then the common trend assumption would not hold. Fortunately, we can use measures of our dependent variable, $\mathrm{PM}_{2.5}$ level, prior to any possible influence of the intervening policy. When we compare the previous five-year average $\mathrm{PM}_{2.5}$ levels across our sample, we see that the trends are roughly parallel (Figure A1, panel a). We test this pattern by comparing the model of the time series without a control for religiosity to a model with a control for religiosity, finding the two models are statistically indistinguishable $(F(1)=0.4606, p=0.4974)$. Moreover, in our sample $\mathrm{PM}_{2.5}$ levels are not significantly different across days of the week $(F(1588)=0.0136, p>$ 0.1). Hence, the common trend assumption holds in our case. 
a.

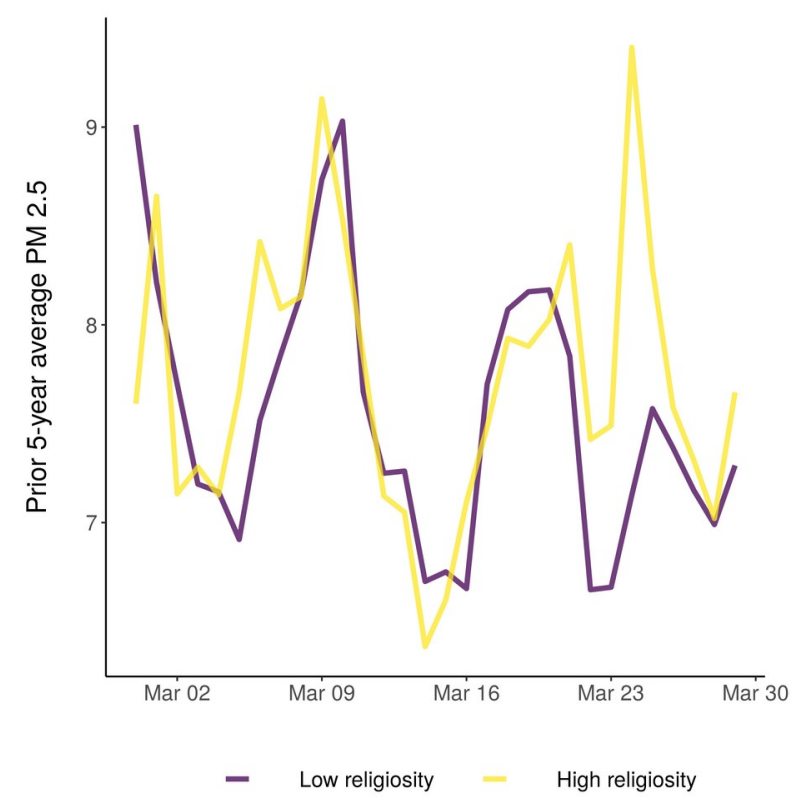

b.

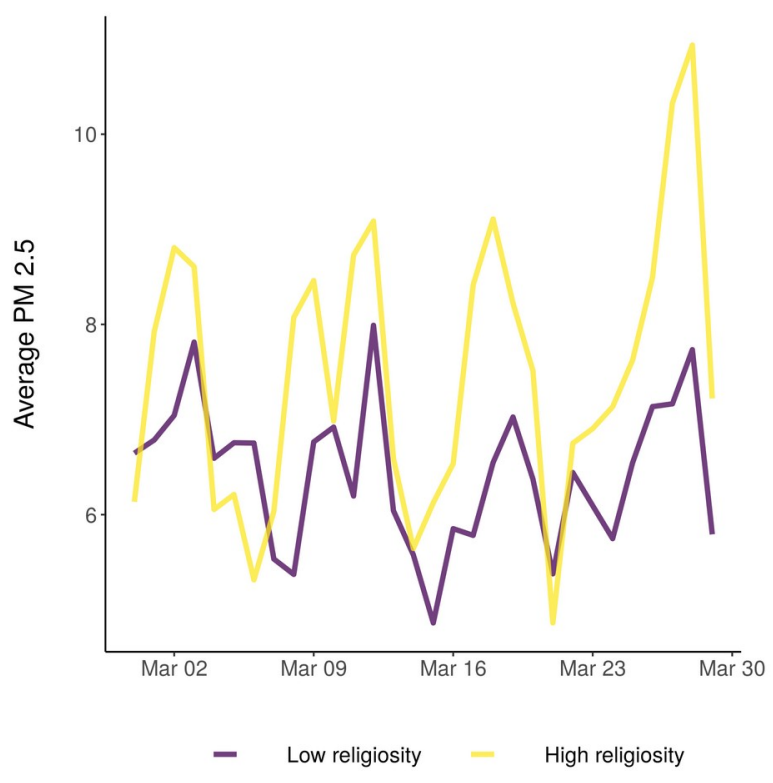

Figure 1a. The trend of average $\mathrm{PM}_{2.5}$ levels over the previous five years (panel a) is roughly parallel between high- and low- religiosity communities. The trend of $\mathrm{PM}_{2.5}$ between groups in the period of analysis shows a divergence from this historical norm (panel b).

We next test for strict exogeneity (Wing et al., 2018) by showing that instituting a shelterin-place directive is not predicted by changes in $\mathrm{PM}_{2.5}$ levels $(\beta=-0.0417, p>0.1)$. Similarly, it may be possible that the order of adoption of the policy may influence the result, either because adoption introduces a spike in preparation activities followed by a drop in activity, or because those cities with lower religiosity were more likely to adopt early. We test the former by including a control for the number of days since the shelter-in-place directive was put in place, which makes no qualitative difference in the results. We test the latter by using a leave-one-out analysis, dropping one metropolitan area at a time and comparing the resulting model to our fully specified model. After fitting all 52 such models, we find that $90.57 \%$ are statistically 
indistinguishable from our original model. Across 52 models, the median coefficient of interaction between religiosity and shelter-in-place directives was 1.8448 .

An additional robustness check addressed the possible criticism that the cities in the sample that never instituted shelter-in-place directives during the observation period were somehow distinct and influenced the results of the overall model. While this is largely controlled by using metropolitan area-level random effects and testing the phenomenon through a difference-in-differences paradigm, in addition to testing the model with an extended date range (see Appendix F), we add additional evidence against this criticism by removing these cities from the data set and refitting the model. The focal interaction between religiosity and shelter-inplace directives without these metropolitan areas remains significant $(\beta=0.382, p=0.0028)$.

\section{Supplemental Material D: Additional Measures of Religiosity}

To further test the robustness of the observed phenomenon, we replace our main measure of religiosity, congregations per 10 thousand residents, with two alternate variables. The first is the total number of adherents reported by congregations, per 10 thousand residents. The second is a calculated variable based on national denomination-level responses stating religion in very important in an individual's life (see Appendix A). Results are detailed in Table A3.

Table A3.

Regression results using alternate measures of religiosity.

\begin{tabular}{lcc}
\hline & Religious Adherents & Religious Importance \\
Variable & $\beta$ & $\beta$ \\
Intercept & $(\mathrm{SE})$ & $(\mathrm{SE})$ \\
& 9.7469 & 9.5899 \\
COVID cases confirmed & $(11.4513)$ & $(9.3897)$ \\
& $-0.0021^{*}$ & -0.00001 \\
COVID deaths & $(0.0009)$ & $(0.0008)$ \\
& 0.0442 & -0.0027
\end{tabular}




\begin{tabular}{lcc} 
& $(0.0262)$ & $(0.0243)$ \\
Precipitation & $-0.0041^{* * *}$ & $-0.0042^{* * *}$ \\
Five year $\mathrm{PM}_{2.5}$ average & $(0.001)$ & $(0.001)$ \\
& -0.0254 & -0.0223 \\
Day of the week & $(0.0413)$ & $(0.0412)$ \\
& 0.0167 & 0.0156 \\
Bachelor's degree attainment & $(0.1038)$ & $(0.0967)$ \\
& -0.0108 & -0.0154 \\
Unemployment & $(0.1617)$ & $(0.1334)$ \\
& -0.3831 & -0.1897 \\
Poverty rate & $(0.2456)$ & $(0.2447)$ \\
& -0.0293 & -0.0374 \\
Social membership groups & $(0.4206)$ & $(0.3519)$ \\
& 0.0004 & 0.0005 \\
Adherents per 10k residents & $(0.001)$ & $(0.0008)$ \\
Religious Importance & -0.0001 & \\
State-level shelter-in-place & $(0.0902)$ & -0.01853 \\
directive & & $(0.3419)$ \\
State-level shelter-in-place X & & $-4.1146^{* * *}$ \\
Religious adherents & $-5.1491^{* * *}$ & $(0.9984)$ \\
State-level shelter-in-place X & $(1.5312)$ & \\
Religious importance & $0.1031^{* *}$ & \\
$R^{2}$ & $(0.0339)$ & $0.6858^{* * *}$ \\
$X^{2}$ & & $(0.1851)$ \\
\hline Note: $* p<0.05, * * p<0.01, * * * p<0.001$. & $50.985^{* * *}$ \\
\hline
\end{tabular}

\section{Supplemental Material E: Political Interactions}

Since we are primarily interested in reactance to state-issued directives, it is possible that when a directive is issued by a governor of a different party than the majority of those in the metropolitan area, adherence will decrease. We test this with a three-way interaction between the party of the governor, the religiosity of a community, and the presence of a state-issued shelterin-place directive (see Table A4). Similarly, it may be possible that there is a three-way interaction with the majority political alignment of the metropolitan area, the religiosity of the metropolitan area, and the presence of a state-issued shelter-in-place directive (see Table A4). 
Finally, we test the presence of the interaction between state-issued shelter-in-place directive and majority political alignment of the metropolitan area, finding it to be significant when on its own, but insignificant when we also consider the interaction between religiosity and a state-issued shelter-in-place directive (see Table A4).

Table A4

Regression results including interactions with political identity variables.

\begin{tabular}{|c|c|c|c|c|}
\hline Variable & $\begin{array}{c}\text { Governor party } \\
\beta \\
(\mathrm{SE})\end{array}$ & $\begin{array}{c}\text { Political identity } \\
\beta \\
(\mathrm{SE})\end{array}$ & $\begin{array}{c}\text { Political identity } \\
\text { interaction } \\
\beta \\
(\mathrm{SE})\end{array}$ & $\begin{array}{c}\text { Political identity } \\
+ \text { Religiosity } \\
\text { interaction } \\
\beta \\
\text { (SE) }\end{array}$ \\
\hline Intercept & $\begin{array}{l}10.6856 \\
(8.7839)\end{array}$ & $\begin{array}{c}9.5303 \\
(11.4407)\end{array}$ & $\begin{array}{l}-1.2829 \\
(9.9377)\end{array}$ & $\begin{array}{c}-0.9907 \\
(10.5112)\end{array}$ \\
\hline $\begin{array}{l}\text { COVID cases } \\
\text { confirmed }\end{array}$ & $\begin{array}{l}-0.0005 \\
(0.0008)\end{array}$ & $\begin{array}{l}-0.0002 \\
(0.0008)\end{array}$ & $\begin{array}{l}-0.0003 \\
(0.0008)\end{array}$ & $\begin{array}{l}-0.00002 \\
(0.0008)\end{array}$ \\
\hline COVID deaths & $\begin{array}{c}0.0111 \\
(0.0247)\end{array}$ & $\begin{array}{c}0.0015 \\
(0.2434)\end{array}$ & $\begin{array}{c}0.0049 \\
(0.0241)\end{array}$ & $\begin{array}{l}-0.0014 \\
(0.0243)\end{array}$ \\
\hline Precipitation & $\begin{array}{c}-0.0039^{* * *} \\
(0.001)\end{array}$ & $\begin{array}{c}-0.0041^{* * *} \\
(0.001)\end{array}$ & $\begin{array}{c}-0.0039^{* * *} \\
(0.001)\end{array}$ & $\begin{array}{c}-0.0041^{* * *} \\
(0.001)\end{array}$ \\
\hline Five year $\mathrm{PM}_{2.5}$ average & $\begin{array}{l}-0.0254 \\
(0.0411)\end{array}$ & $\begin{array}{l}-0.0244 \\
(0.0413)\end{array}$ & $\begin{array}{l}-0.0187 \\
(0.0412)\end{array}$ & $\begin{array}{l}-0.0188 \\
(0.0412)\end{array}$ \\
\hline Day of the week & $\begin{array}{c}0.0169 \\
(0.0987)\end{array}$ & $\begin{array}{c}0.0154 \\
(0.0971)\end{array}$ & $\begin{array}{c}0.0142 \\
(0.0978)\end{array}$ & $\begin{array}{c}0.0155 \\
(0.0969)\end{array}$ \\
\hline $\begin{array}{l}\text { Bachelor's degree } \\
\text { attainment }\end{array}$ & $\begin{array}{l}-0.0216 \\
(0.1247)\end{array}$ & $\begin{array}{l}-0.0114 \\
(0.1599)\end{array}$ & $\begin{array}{c}0.1049 \\
(0.1569)\end{array}$ & $\begin{array}{c}0.0996 \\
(0.1661)\end{array}$ \\
\hline Unemployment & $\begin{array}{l}-0.2901 \\
(0.2489)\end{array}$ & $\begin{array}{l}-0.1905 \\
(0.2475)\end{array}$ & $\begin{array}{l}-0.2223 \\
(0.2399)\end{array}$ & $\begin{array}{l}-0.2057 \\
(0.2403)\end{array}$ \\
\hline Poverty rate & $\begin{array}{l}-0.0452 \\
(0.294)\end{array}$ & $\begin{array}{l}-0.0295 \\
(0.4104)\end{array}$ & $\begin{array}{c}0.2621 \\
(0.3344)\end{array}$ & $\begin{array}{c}0.2564 \\
(0.3538)\end{array}$ \\
\hline $\begin{array}{l}\text { Social membership } \\
\text { groups }\end{array}$ & $\begin{array}{c}0.0005 \\
(0.0006)\end{array}$ & $\begin{array}{c}0.0004 \\
(0.0009)\end{array}$ & $\begin{array}{c}0.0002 \\
(0.0008)\end{array}$ & $\begin{array}{c}0.0002 \\
(0.0008)\end{array}$ \\
\hline $\begin{array}{l}\text { Political party of } \\
\text { governor }\end{array}$ & $\begin{array}{l}-1.1651 \\
(3.2317)\end{array}$ & $\begin{array}{l}-0.1595 \\
(1.5378)\end{array}$ & $\begin{array}{c}0.1352 \\
(1.2453)\end{array}$ & $\begin{array}{c}0.1059 \\
(1.3169)\end{array}$ \\
\hline Majority party voting & $\begin{array}{l}-0.0916 \\
(2.2267)\end{array}$ & $\begin{array}{l}-0.1822 \\
(6.1204)\end{array}$ & $\begin{array}{c}1.3779 \\
(2.6373)\end{array}$ & $\begin{array}{c}1.4699 \\
(2.7905)\end{array}$ \\
\hline $\begin{array}{l}\text { Congregations per } 10 \mathrm{k} \\
\text { residents } \\
\text { State-level shelter-in- }\end{array}$ & $\begin{array}{l}-0.0714 \\
(0.3469) \\
-1.8858\end{array}$ & $\begin{array}{l}-0.0336 \\
(0.6467) \\
-2.3645^{*}\end{array}$ & $\begin{array}{c}0.0575 \\
(0.2568) \\
-2.6846^{* * *}\end{array}$ & $\begin{array}{c}0.0414 \\
(0.2719) \\
-3.997^{* * *}\end{array}$ \\
\hline
\end{tabular}


place directive

(0.9936)

State-level shelter-in-

place X Religious

congregations

State-level shelter-in-

place X Majority party

State-level shelter-in-

place X Religious

congregations $\mathrm{X}$

0.4762

(0.3739)

$0.3149^{*}$

(0.1569)

$2.5208^{* *}$

1.3263

(0.8276)

(1.0195)

Governor party

State-level shelter-in-

$-0.646$

place X Religious

(0.8374)

congregations $\mathrm{X}$

Majority party

$R^{2}$

$\frac{\chi^{2}}{66.5431^{* * *}} 52.7781^{* * *}$

$0.0243 \quad 0.0266$

$0.0408 \quad 0.0326$

$43.001^{* * *}$

\section{Supplemental Material F: Extended Time Period}

Finally, we consider a date range that extends from February 15, 2020 through May 28,

2020 (see Table A5). This allows for the inclusion of states slower to implement shelter-in-place

directives and also includes early repeals of these directives, as discussed in the main text.

Table A5

Regressions results for an extended time period.

Extended Time Period

$\begin{array}{lc}\text { Variable } & \beta \\ \text { Intercept } & 10.1994 \\ & (21.9329) \\ \text { COVID cases confirmed } & 0.0001^{* *} \\ \text { COVID deaths } & (0.00002) \\ \text { Precipitation } & -0.0008^{\dagger} \\ \text { Five year } \mathrm{PM}_{2.5} \text { average } & (0.0004) \\ & -0.0029^{* * *} \\ & (0.0007) \\ & 0.0371 \\ \end{array}$


Running Head: RELIGION AND COVID-19 MITIGATION SUPPLEMENT

Day of the week

$-0.0711$

$(0.2063)$

Days since shelter-in-place

$-0.00002$

Bachelor's degree attainment

$(0.0004)$

Bachelor's degree attainment

$-0.0518$

Unemployment

(0.3117)

$-0.0315^{*}$

Poverty rate

$-0.0327$

Social membership groups

(0.8284)

0.0005

(0.0019)

Congregations per $10 \mathrm{k}$ residents

$-0.0378$

State-level shelter-in-place directive

(0.5706)

$-1.8446^{* * *}$

State-level shelter-in-place directive removed

(0.3122)

$-2.1655^{* * *}$

State-level shelter-in-place X Religious

$(0.5452)$

$0.0887^{* *}$

congregations

(0.0309)

State-level shelter-in-place removed X

$0.1496^{* *}$

Religious congregations

(0.0519)

$R^{2}$

0.0147

$x^{2}$

$91.2593^{* * *}$

Note: $\dagger p<0.06,{ }^{*} p<0.05,{ }^{* *} p<0.01,{ }^{* * *} p<0.001$. 


\section{References}

Dong, E., Du, H., \& Gardner, L. (2020). An interactive web-based dashboard to track COVID-19 in real time. The Lancet Infectious Diseases,20(5).

Grammich, C., Hadaway, K., Houseal, R., Jones, D., Krindatch, A., Stanley, R., \& Taylor, R. (2018). U.S. religion census: Religious congregations and membership study, 2010 (county file). Retrieved from https://osf.io/qun29/

Jaeger, D. A., Joyce, T. J., \& Kaestner, R. (2020). A cautionary tale of evaluating identifying assumptions: Did reality TV really cause a decline in teenage childbearing? Journal of Business \& Economic Statistics, 38(2), 317-326.

Kahn-Lang, A., \& Lang, K. (2019). The promise and pitfalls of differences-in-differences: Reflections on 16 and Pregnant and other applications. Journal of Business \& Economic Statistics, $1-14$.

Menne, M. J., Durre, I., Korzeniewski, B., McNeal, S., Thomas, K., Yin, X., . . Houston, T. G. (2020). Global historical climatology network - daily (GHCN-daily), version 3.

MIT Election Data and Science Lab. (2018). County presidential election returns 2000-2016. Harvard Dataverse. Retrieved from https://dataverse.harvard.edu/dataset.xhtml? persistentId=doi:10.7910/DVN/VOQCHQ

Pew Forum. (2008). U.S. religious landscape survey. Retrieved from https://www.pewforum.org/ religious-landscape-study/

Ryan, A. M., Kontopantelis, E., Linden, A., \& Burgess, J. F. (2019). Now trending: Coping with non-parallel trends in difference-in-differences analysis. Statistical Methods in Medical Research, 28(12), 3697-3711 
Running Head: RELIGION AND COVID-19 MITIGATION SUPPLEMENT

University of Wisconsin Public Health Institute. (2020). County health rankings model: Social associations. County Health Rankings \& Roadmaps. Retrieved from https://www.countyhealthrankings.org

U.S. Census Bureau (2010). Metropolitan and micropolitan statistical areas population totals and components of change: 2010-2019. Retrieved from https://www.census.gov/data/tables/time-series/demo/popest/2010s-total-metro-andmicro-statistical-areas.html

U.S. Census Bureau. (2019a). American Community Survey Data Releases. The United States Census Bureau. Retrieved from https://www.census.gov/programs-surveys/acs/news/data-releases.html

U.S. Census Bureau. (2019b). SAIPE State and County Estimates for 2018. The United States Census Bureau. Retrieved from https://www.census.gov/data/datasets/2018/demo/saipe/2018-state-and-county.html

U.S. Census Bureau. (2020). County Population Totals: 2010-2019. The United States Census Bureau. Retrieved from https://www.census.gov/data/datasets/time-series/demo/popest/2010s-counties-total.html

U.S. Department of Labor. (2020). Unemployment Insurance Weekly Claims Data, Employment \& Training Administration (ETA). The United States Department of Labor. Retrieved from https://oui.doleta.gov/unemploy/claims.asp

U.S. Environmental Protection Agency. (2020). Air data: Air quality data collected at outdoor monitors across the U.S.Retrieved from https://www.epa.gov/airdata 
Wing, C., Simon, K., \& Bello-Gomez, R. A. (2018). Designing difference in difference studies: Best practices for public health research. Annual Review of Public Health, 39(1), 453469. 